\title{
Ideology of Domestication and Foreignization Translation of Madogiwa No Totto-Chan Novel
}

\author{
Translation of Latifah Rahmat, Nandang Rahmat, and Widya Kirana
}

\author{
${ }^{1 s t}$ Poppy Rahayu \\ Indonesian Language Study \\ Programme, Postgraduate of \\ State University of Jakarta. \\ Poppyrahayu.sabri@gmail.co
}

\author{
${ }^{2 n d}$ Emzir \\ Indonesian Language Study \\ Programme, Postgraduate of \\ State University of Jakarta.
}

\author{
${ }^{3 s r d}$ Zainal Rafli. \\ Indonesian Language Study \\ Programme, Postgraduate of \\ State University of Jakarta.
}

$\mathrm{m}$

Abstract--Throughout Japan Association for Interpreting and Translation Studies journal, ideology is a system of ideas and beliefs that are born from the influence of economy base,politic, law, philosophy, moral, and etc., which exist in certain communities. Moreover, it gives aninfluence on society and forms a sense of value, a sense of morality, and aesthetics. ${ }^{1}$ In this context, ideology simply describes as a relationship between society including what kind of society it is and what kind of relationship the society should have.

In terms of translation, it can be concluded that ideology of translation is a correlation between genetic factors and knowledge that shape work behaviour of source-language writer. Furthermore, in the process of translation, the ideology of translationwill be mediated by the translator as a reflection of his genetic factors, knowledge, behaviour and attitude in accordance with the values, norms, and beliefs that he professes and then it will be materialized through his method of translation. Therefore, ideology of translation is a study that reveals how translator's personalityinfluences his work of translation.

In the translation of foreign novel, ideology of domestication and foreignization come as the two important ideologies. These two ideologies will influence the equivalence in translation. Ideology of foreignization tends to use formal equivalence whereas domestication ideology tends to use dinamic equivalence. In many cases, there are fators causing a translator to use either ideology of domestication or foreignization, or even both of them.

This research focuses on the ideology of translation and its implementationon two Japanese translation novels with education genre entitled Madogiwa no Totto-chan by Tetsuko Kuroyanagi that translated into Indonesian by LatifahRahmat, NandangRahmat,

\footnotetext{
${ }^{1}$ YIN, Yongsun. "The effect of ideology on writing in the Chinese version of Kagi: Focusing on the content associated with 'sex' Interpreting and Translation Studies.No.11,2011.pp. 123-126 by The Japan Association For Interpreting Translation Studies.
}

andWidyaKirana. In ideology of translation, the subject matter is to what extend the mediation from many texts provided by the translator.

In this research, the method used is Content Analysis. On the other hand, the research used descriptive-qualitative approach with product-oriented case study design in which it analyzed objective, affective and genetic aspect. In addition, this research used qualitative data analysis technique through concept "Philip Mayring content analysis model"2

As a result of data interpretation of domestication and foreignization ideology in translationconducted by Latifah Rahmat and Nandang Rahmat, it seems that genetic factor, knowledge, behaviour and personality of a translator are reflected in their work of translation. Nevertheless, another factor that also influences the translation is the mision of the book translation as a medium to introduce Japanese language and culture. This condition was presented by the data in whichthe use of both ideology of domestication and foreignization becomethe highest ideology of translation through the data results showing 32 of 73 data $(44 \%)$ used these two ideologies. From 73 data, there are 15 data $(20 \%)$ that only used ideology of foreignization and 26 data (36\%) used ideology of domestication. The use of both ideology of domestication and foreignization aims to be able to reach the goals of all readers.

In addition, through data interpretation of domestication and foreignization ideology in translation, Widya Kirana concretely used ideology of foreignization on 24 of 71 data (34\%) and used ideology of domestication on 32 of 71 data $(45 \%)$. The use of both ideology of domestication and foreignization, however, only used on 15 of 71 data (21\%). Generally, the dominant use of ideology of domestication is chosen for the convenience of the readers.

Key words: ideology of translation, Madogiwa no Tottochan.

\footnotetext{
${ }^{2}$ Ismail Nawawi, MetodepenelitianKualitatif, h.249
} 


\section{INTRODUCTION}

Allah SWT grant human with brains and minds. Ideology was born from these brains and minds. Ideology was found by Antoine Destutt Tracy (1757b-1836), a French philosopher. According to him, ideology is the branch of philosophy that is called science de ideas (science of ideas). In the year of 1796, he defined ideology as a knowledge about human's thoughts that is able to show the right path to the future. Therefore, in the year of its emergence, ideology means knowledge about the process of aspirations, ideas, and thoughts.

In journal of The Japan Association For Interpreting and Translation Studies, Ideology is a system of ideas nd beliefs that was born by the influence of the basis of economy that was planted in certain society, and it includes the influence of politic, law, philosophy, morals, etc. in this case, it gave effect one by one on society and it formed values, morals, and aesthetics ${ }^{3}$. In this context, ideology is simply described as a relation between society, such as how the society is like, and how this society connects with each other.

The definition of Levefere's ideology is not only limited by a scope of politics, but it is also limited by the form of patterns that is stuck on our systems of behavior, habit, and belief within the society. in addition, accoring Levefere, ideology is a concept which is a result of manner and the way people think that could be accepted in a society on a certain era.

The reality showed that there is nothing in this world is set apart from ideology. For example, Basnett and Levefere's statement that was quoted by Hoed $^{4}$ that no matter what the purpose, every reproduction is shadowed by certain ideologies. Then what happens when ideology enters the field of translation?

If it is viewed from ideology's aspect in the field of translation, after we feel like there are textual strategies that has a strong relation with cultural beliefs, values and hope, it is seen how ideology influences the art of translation. This is not a new thing. Hermans (1985), Basnett and Lefevere (1990) proved the existence of ideology in translation of

\footnotetext{
${ }^{3}$ YIN, Yongsun. "The effect of ideology on writing in the Chinese version of Kagi: Focusing on the content associated with 'sex' Interpreting and Translation Studies.No.11,2011.pp. 123-126 by The Japan Association For Interpreting Translation Studies.

${ }^{4}$ Ibid.,h.83
}

literary works: Venuti (1995) showed a high consequence from the orientation of basic translation-all of it reflected the focus that has been a debate inside the translation of literary work in the past years.

In the past few decades, the research about ideology inside a language leads to a significant improvement through Fowler's work and his colleagues (1979), Hodge and Kress (1993), Fairclough (1989) and others. The concept that is given by the mentioned scientists granted a concept about how ideology forms a discourse and the way how the discourse is practiced to keep, strengthen, and refuse ideology. This concept shows how a translator functions as a communicator. In that way, it will be shown the proof of an ideological consequence that has been selected by the translator through contextual details of linguistic inside transition. ${ }^{5}$

As we have known before, translating is not a neutral activity. Phrase like traduttore-traditore, les belles, and others exist inside literary works. A thing about the freedom of translating in a translation has always been intense. An ideology matter of translation is also located in the ethic code of translation that a translation has to be as literal as possible. Not to be seen as a new work. What the original writer wants a "certain thing" to be delivered, has to be delivered by the translator. However, the original writer does not want their works to be translated and became unnatural and unacceptable, especially literary works translation. In the other side, a translator orientates on the readings of target's language readers. In this matter, a translator has to have the ability of mediation that is sharp enough as a communicator between the original writer and the target's language readers.

A famous critique from Nabokov (1964) against a free translation is a characteristic of term that has been set and debated was about this. Many writers see the choices of translation in-between two polarities, that is "freedom" and "literal", "dynamic equality" and "formal equality" (Nida 1964); a "communicative" and "semantic" translation (Newmark 1981), those choices lead to a dichotomy. Newmark (1981:62) proved that choices between communicative and semantic as a dichotomy. Newmark (1981:62) showed that choices between communicative and semantic are determined by social and individual orientation, and also to the amount of readers or personal opinions from the text. These choices are implied ideologically. However, Venuti (1995) believed in ideological consequences

\footnotetext{
${ }^{5}$ Translator As Communicator
} 
of each choice. With differing "domestic" and "foreign" translation, he appointed how tendency of trend is dominating in domestic translation of AngloAmerican in the past three centuries have an effect to normalization and neutralization with eliminating an original source of text and expressing foreign cultural value that has been known (also does not resist) to the dominant culture and 'creating a transparent illusion in which the there is differences between linguistic and a domesticated culture' (Venuti 1995:34). He questioned either domestication of the foreign value (for example, the text source) is an important process that was done consciously or not to acknowledge the similar effect, is to assimilate dominant culture, or even hegemony culture, which is foreign to those cultures. Therefore, according to Venuti, a translator could not avoid the basic choice of ideologies and what has been appointed by another writers as a personal preference that can be seen as a commitment $^{6}$

It is no doubt that translator often strengthen or even against the dominant culture's code. It is important to understand that this domestic's view happens in a situation where a target's language, not an origin's language, is a dominant culture. Otherwise, if the domestic's strategies were adopted on a case of translation from an origin's language that has a cultural aspect that is dominant to a target's language which is minority, that thing will help to protect ideology that is against tendency that language will be absorbed and damaged by the practical text of origin's language. ${ }^{7}$

Therefore, it is not domestic or foreign language that could "hijacked culturally" or in other word, has a tendency whose side it is on ideologically but that thing is more of the influence of certain strategies that are used on some social cultural situation that has a big possibility of involving ideology. A translator plays a role in a social context and even becomes a part of that context. In this situation, we could comprehend that the process of translating itself is an activity that is involving ideology. With understanding all of these things, the focus would be on how ideology is being translated, either with domestic method or foreign methods, and how is the result. Culture in target's language can have different opinions, beliefs and valuable systems that can be seen in original language. Variety of translations in every aspects inside the text describes the level of ideology inside a text. to make it simple, a translator, as the processor, refines texts from the original text

\footnotetext{
${ }^{6}$ Translator as Communicator

${ }^{7}$ Translator as Communicator
}

through their point of view or their own ideology, with different results. The level of mediation of each translator does not always fit with the level of domestication. $^{8}$

With a background of those experts, the research is done with analyzing two novels that have been translated Madogiwa no Totto-chan, the work of Tetsuko Kuroyanagi, the result of translation from Latifah Rahmat and Nandang Rahmat team, also the result of translation from Widya Kirana. These two translations seem relatively different. The translations reflect pictures of the consistency choices from the ideology of translation and the possibility of influence from certain factors on each case. This research only digs translations of 62 titles, and the procedure of domestication and foreignization.

Hatim dan Mason (1997: 147) declared:

For Hatim and Mason, ideology encompasses the tacit assumption, beliefs and value system which are shared collectively by social groups' (1997:144). They make a distinction between 'the ideology of translating' and 'the translation of ideology'. Whereas the former refers to the basic orientation chosen by the translator operating within a social and cultural context (the choice, for example, between Venuti's domesticating and foreignizing translation), in the translation of ideology they examine the extent of mediation supplied by a translator of sensitive teks. 'Mediation' is defined as 'the extent to which translators intervence in the transfer process, feeding their own knowledge and beliefs into processing the text' (Hatim and Mason 1997: 147) ${ }^{9}$

Hatim and Mason's statement annunciated that differences has got to be made in the first start, that would be the differences between the ideology of translation and translation of ideology because these two issues are highly related and will be prominent for those who has been practicing their skills of translating officially. The level of mediation of translator is the kind of ideological issue that influences the ideology of translation and translation of ideology with a main focus that is oriented on these translators. Is the text successfully delivered or not to those receivers of text in a different cultural and linguistic environment. In other words, either the interversion of translation is filtered directly or not.

\footnotetext{
${ }^{8}$ Translator as Communicator (combination of some paragraphs)

${ }^{9}$ Translator as Communicator part 9 paragraph 1
} 
Based on a basic assumption of some theories about ideology of translation, scientists concluded that ideology of translation is a correlation between genetic factors and knowledge that formed the behavior of the way a writer of original language create their arts and in translating the art, a translator would mediate it as a reflection from genetic factor, knowledge, behavior and attitude that is actualized on the way translators work with values, norms, and belief.

So, Ideology of translation is a study that reveals the identity of translators might have influence on their work of translation. This ideology of translation could appear on meaning, translating style through linguistic features or cultural features that the appearance of it is influenced by the ideological genetic of translation itself.

If a translator finds an ideological text that could not be accepted in society and against the ideology of translation, then the ideological text itself will tend to be mediated. The mediation that is mentioned here is the effort of translators based on their ideology, inserting their knowledge, ideology, and belief to the text that has been translated. This case works for the translators, it is important for a translator to know so that the translation would be consistent with the vision and mission of their translations.

\section{METHODS}

The methodology that is used for this research of translation of Madogiwa no Totto-Chan novel in Indonesian language is Content Analysis.

According to Klaus Krippendorff (2006:16), Content Analysis is a research technique for making replicable and valid inferences from texts (or other meaningful matter) to the cointext of their use. (This analysis is a research technique in order to make a duplication and conclusion becomes valid (or meaningful) from the text to its contextual use. Meanwhile, in investigating ideology of translation from both translators of Madogiwa no Totto-Chan novel to Indonesian language, the research would be using descriptive-qualitative approach with designing case study and orienting on products that reviews objective, affective, and genetic aspects.

As for the data analysis technique applied is qualitative data analysis using the concept of "Philip Mayring's content analysis" 10

\footnotetext{
${ }^{10}$ Ismail Nawawi, Metode penelitian Kualitatif, pg. 249
}

The purpose of research that would like to be accomplished are:

1. Identifying how translator's ideology affect his translation in the novel Madogiwa no Totto-Chan?

2. Describing how the translator translates ideology text in his translation?

3. Identifying domestification foreignisation and the chosen as translator's ideology in the translation of Madogiwa no Totto-Chan novel from Japanese language to Bahasa Indonesia.

\section{RESULTS AND DISCUSSION}

\section{Madogiwa no Totto-Chan novel}

Madogiwa no Totto-Chan is a novel with education genre as well as an autobiography from its author, Tetsuko Kuroyanagi, a Japanese who had her childhood before World War II. This novel became very universal for all readers from all ages. It needs a high skill in translating the novel because it should reach the interests and comfort for its readers as the novel is also an entertainment platform for the society.

This novel was first translated by a group of lecturers of Japanese Literature from Padjajaran University, they are husband and wife, Mrs. Latifah Rahmat and Mr. Nandang Rahmat. Mr. Nandang Rahmat is an Indonesian, while his wife is Japanese. Along with some improvements, this novel was later re-translated by Widya Kirana, a translator from publishing company, Gramedia Jakarta, with reference to its translation in English.

The degree of difficulty in translating the novel is quite high because as an autobiography novel, the translator is limited to develop the ideology of translation. Also, the novel still has to keep its humorous style yet the values for education should be delivered well using its language style which still meets the taste of readers.

Therefore, the famous re-structurisation of Shakespeare's work, Dr. Johnson (1790-1784), in the life of Paus (1779-1780), discussed the problem of adding text in the process of translation. He commented that neatness can be obtained by adding something in the translation which is agreed by the readers as long as there is no sentences omitted as the purpose of the author "has to be read". The important element in translation of eighteenth century is related 
to the change of the 'originality' concept. It stated that it is individual right to discuss a work on its own term and its own place.

From the classification of translation study according to Holmes, the ideology of translation is included in the descriptive translation study as it is related to sociology and psychology. Thus, the actual ideology implies behind the structure, whether it is linguistics or textual structure. Learning translation ideology means learning all signs of "semiotic" related to the translator's ideology.

\section{Translation of the title of the novel}

Tetsuko Kuroyanagi as the author of this autobiography novel got the idea for her title of Japanese novel from a popular phrase a few years ago before the novel was written, which referred to someone "at the window", which means they are near to the window or outside in the cold. During her childhood, Totto-chan usually stood at the window because of her own choice, while wishing she could see street musician. Totto-chan feels if she stays "at the window", it would make her an outcast and isolate her. That is the situation chosen by the author, even though on the other side, staying at the window is a sign of a journey to happiness which will finally be revealed for Totto-chan in her new school, Tomoe Gakuen.

\section{Translation of the sub-titles}

The title "Madogiwa no Totto-chan" was translated by Latifah Rahmat and Nandang Rahmat as "Gadis Cilik di Jendela" (Little girl at the window). However, when the title appeared in the sub-title, Madogiwa no Totto-chan was consistently translated the same by WK, but L\&N translated it to "Si Gadis Kecil di Tepi Jendela" (The little girl at the window). The use of "si"(the) shows "nickname" for Totto-chan which is "Si Gadis Kecil di Tepi Jendela" (The little girl at the window).

Example of Domestication and Foreignization Ideology Data Analysis

\begin{tabular}{|c|c|c|c|}
\hline No. & Text of Source Language (SL) & $\begin{array}{c}\text { Text of Target Language (TL) } \\
\text { Widya Kirana (W) }\end{array}$ & $\begin{array}{l}\text { Text of Target Language } \\
\text { (TL) Latifah Rahmat and } \\
\text { Nandang Rahmat (L\&N) }\end{array}$ \\
\hline 1. & $\begin{array}{l}\text { (pg. 21) } \\
\Gamma \ldots \circ \text { 初めての図画の時間のことですが、国旗を } \\
\text { 描いてごらんなさい、...」 } \\
\text { “.....Hajimete no zuga no jikan no koto desu ga, kokki } \\
\text { wo kaite goran nasai,...”. }\end{array}$ & $\begin{array}{l}\text { I asked for the children to draw } \\
\text { Japanese Flag. (domestication } \\
\text { ideology) }\end{array}$ & $\begin{array}{l}\text { At the first meeting of drawing } \\
\text { lesson, I asked for the children } \\
\text { to draw Hinomaru national } \\
\text { flag (domestication and } \\
\text { foreignization ideology) }\end{array}$ \\
\hline 2. & $\begin{array}{l}\text { (pg. 21) } \\
\Gamma \ldots \text {...っ。よく青年団とか、そういった旗につい } \\
\text { てます、あの、ふさです。」 } \\
\text { “..... fusa. Yoku seinendan toka, sou itta hata ini } \\
\text { tsuitemasu. Ano, fusa desu.” }\end{array}$ & $\begin{array}{l}\text { Tassels! } \\
\text { Imagine, like tassels on a banner. } \\
\text { (domestication ideology) }\end{array}$ & $\begin{array}{l}\text { Tassel as often seen on } \\
\text { seinendan flag, youth } \\
\text { community. (domestication } \\
\text { and foreignization ideology) }\end{array}$ \\
\hline 3. & $\begin{array}{l}\text { pg. } 45 \\
\text { トットちゃんの隣の女の子は、もう、ひらがなが } \\
\text { 書けるらしく、ノートに写していた。 } \\
\text { Totto-chan no tonari no ko wa, mou, hiragana ga kakeru } \\
\text { rashiku, nooto ini utsushiteita. }\end{array}$ & $\begin{array}{l}\text { The little girl beside Totto-chan } \\
\text { has memorized alphabets and she } \\
\text { is writing the order of alphabet in } \\
\text { her notebook. (domestication } \\
\text { ideology) }\end{array}$ & $\begin{array}{l}\text { The little girl beside Totto } \\
\text { seems to advance in writing } \\
\text { Hiragana letter and she is } \\
\text { copying Hiragana in her } \\
\text { notebook. (foreignization } \\
\text { ideology) }\end{array}$ \\
\hline 4. & 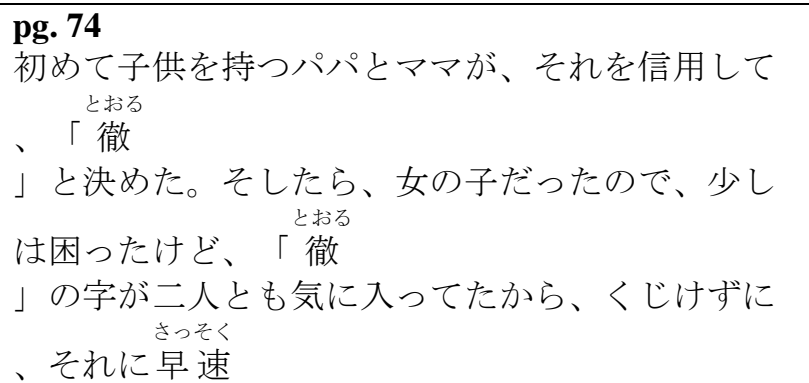 & $\begin{array}{l}\text { But they like Chinese letter for } \\
\text { tooru 徹 (which means piercing } \\
\text { and flowing far, clear, and } \\
\text { echoing like a sound), therefore } \\
\text { they use that letter for girls' } \\
\text { names using Chinese tetsu term } \\
\text { and add suffix ko which is usually } \\
\text { used for girls' names. } \\
\text { (domestication ideology) }\end{array}$ & $\begin{array}{l}\text { Papa and mama which are } \\
\text { waiting for their first baby } \\
\text { born seem to believe it, and } \\
\text { they decide to give her } \\
\text { daughter a name "Tooru" } \\
\text { which consists of a single } \\
\text { kanji letter and is one of the } \\
\text { ways to read kanji "Tetsu". } \\
\text { However, because they love }\end{array}$ \\
\hline
\end{tabular}




\begin{tabular}{|c|c|c|c|}
\hline & $\begin{array}{l}\text { 「子」をつけて、「徹子」としたのだった。 } \\
\text { Hajimete kodomo wo motsu papa to mama ga sore } \\
\text { shinyou shite, “Tooru” to kimeta. Soshitara, onna no ko } \\
\text { datta node, sukoshi wa komatta kedo, “Tooru”no ji ga } \\
\text { futaritomo ki ni itteta kara, kujikezuni, sore ni sassoku, } \\
\text { "ko" wo tsukete, "Tetsuko"to shita no datta. }\end{array}$ & & $\begin{array}{l}\text { the letter 'Tooru' and 'Tetsu' } \\
\text { so much, they do not } \\
\text { discourage themselves to add } \\
\text { 'ko' letter as the last. It then } \\
\text { becomes a name of Tetsoku, a } \\
\text { girl's name. (domestication } \\
\text { and foreignization ideology) }\end{array}$ \\
\hline 5. & 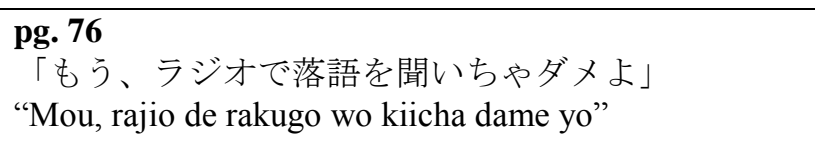 & $\begin{array}{l}\text { "You cannot listen comedy show } \\
\text { on the radio anymore", } \\
\text { (domestication ideology) }\end{array}$ & $\begin{array}{l}\text { "You cannot listen Rakngo on } \\
\text { the radio anymore", } \\
\text { (foreignization ideology) }\end{array}$ \\
\hline 6. & $\begin{array}{l}\text { pg. } 77 \\
\text { ところが、昨日の夕方、弦楽四重奏の練習のため } \\
\text { に、パパのオーケストラの仲間が、トットちやん } \\
\text { の家の応接間に集まったときだった。 } \\
\text { Tokoro ga, kinou no yuugata, genrakushijuusou no } \\
\text { renshuu no tame ni, papa no ookesutora no nakama ga, } \\
\text { Totto-chan no ie no ousetsukan ni atsumatta toki datta. }\end{array}$ & $\begin{array}{l}\text { Last night, some of papa's friends } \\
\text { from the orchestra came to their } \\
\text { house to practice for string } \\
\text { quartets in the guest room. } \\
\text { (domestication and foreignization } \\
\text { ideology) }\end{array}$ & $\begin{array}{l}\text { Papa's friends played } \\
\text { orchestra and gathered in the } \\
\text { guest room. They were } \\
\text { practicing music. } \\
\text { (domestication ideology) }\end{array}$ \\
\hline 7. & $\begin{array}{l}\text { pg. } 82 \\
\text { この電車は、大井町の操車場から、トラクターで } \\
\text { 、運ばれて来たのだった。 } \\
\text { Kono densha wa, Ooimachi no soushajou kara, torakutaa } \\
\text { de, hakobarete kita no datta. }\end{array}$ & $\begin{array}{l}\text { The wagon is carried by big } \\
\text { trailer-cart connected to truck- } \\
\text { which is pulled by Oimachi's } \\
\text { railway workshop's tractor. } \\
\text { (foreignization ideology) }\end{array}$ & $\begin{array}{l}\text { That electric trains are carried } \\
\text { from a carriage place in } \\
\text { Oimachi using tractor. } \\
\text { (domestication ideology) }\end{array}$ \\
\hline 8. & $\begin{array}{l}\text { pg. } 89 \\
\text { 家に着いて、玄関の戸を開けると、トットちゃん } \\
\text { は「ただいま」といってから、ロッキーを探した } \\
\text { 。 } \\
\text { Ie ni tsuite, genkan no to wo akeru to, Totto-chan wa } \\
\text { "tadaima” to itte kara, Rokkii wo sagashita. }\end{array}$ & $\begin{array}{l}\text { As soon as she got home, Totto- } \\
\text { chan opened the front door and } \\
\text { shouted, "I am home!"' and } \\
\text { looked for Rocky. (domestication } \\
\text { ideology) }\end{array}$ & $\begin{array}{l}\text { As she arrived home and } \\
\text { opened the door porch, Totto } \\
\text { said, "Tadaima (I am } \\
\text { coming)." (domestication and } \\
\text { foreignization ideology) }\end{array}$ \\
\hline 9. & $\begin{array}{l}\text { pg. 90 } \\
\text { そこには、甲とか乙とか、いろんな字が書いてあ } \\
\text { った。 } \\
\text { Soko ni wa, kou toka otsu toka, ironna ji ga kaite atta. }\end{array}$ & $\begin{array}{l}\text { The letters are A, B, and others. } \\
\text { (domestication ideology) }\end{array}$ & $\begin{array}{l}\text { In there, written various kinds } \\
\text { of kanji letter like Ko and } \\
\text { Otsu which is the school's } \\
\text { score. (foreignization } \\
\text { ideology) }\end{array}$ \\
\hline 10. & 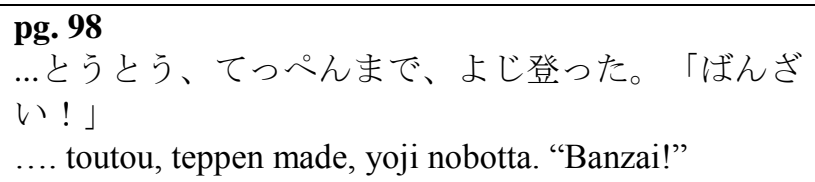 & $\begin{array}{l}\text { She finally succeeded reaching } \\
\text { upstairs. "Hurray!", } \\
\text { (domestication ideology) }\end{array}$ & $\begin{array}{l}\text { They cheered happily } \\
\text { "Banzai!", (foreignization } \\
\text { ideology) }\end{array}$ \\
\hline 11. & $\begin{array}{l}\text { pg. } 123 \\
\text { 縁日は、前に行ってた学校のそばにある } \\
\text { せんそく } \\
\quad \text {,洗足 } \\
\text { 池の、弁天様がある小さい島でやっていた。 } \\
\text { Ennichi wa, mae ni itteta gakkou no soba ni aru } \\
\text { Sensoku-ike no, Benten-sama ga aru chiisai shima de } \\
\text { yatte ita. }\end{array}$ & $\begin{array}{l}\text { In the middle of Senzoku pond, } \\
\text { which is near her old school, there } \\
\text { is a small island with temple } \\
\text { which built in honor to Benten, } \\
\text { Goddess of music and aesthetic. } \\
\text { (domestication and foreignization } \\
\text { ideology) }\end{array}$ & $\begin{array}{l}\text { Night market opened in the } \\
\text { small island which has Benten } \\
\text { temple (Goddess of } \\
\text { Happiness) in the middle of } \\
\text { Senzoku pond which near her } \\
\text { old school. (domestication and } \\
\text { foreignization ideology) }\end{array}$ \\
\hline 12 & $\begin{array}{l}\text { pg. 124 } \\
\text { 犬とが猫とかベティーさんなどの顔がパイプにな } \\
\text { つている。 } \\
\text { Inu to neko toka Beti-san nado no kao ga paipu ni } \\
\text { natteiru. }\end{array}$ & $\begin{array}{l}\text { Those pipes are decorated with } \\
\text { illustrations of cat, dog, and Betty } \\
\text { Boob. (foreignization ideology) }\end{array}$ & $\begin{array}{l}\text { Those pipes have the shape of } \\
\text { dog head or cat head. } \\
\text { (domestication ideology) }\end{array}$ \\
\hline & pg. 131 & At that time, I must said, 'Can I & And I do it, such as come into \\
\hline
\end{tabular}




\begin{tabular}{|c|c|c|c|}
\hline 13. & $\begin{array}{l}\text { 出るときは、お尻からで、そいで、垣根のはじっ } \\
\text { こから、ずーっと、“ごめんくださいませ”と“では } \\
\text { さようなら”をやるから、 } \\
\text { Deru toki wa, oshiri kara de, soide, kakine no hajikko } \\
\text { kara, zuutto“gomen kudasaimase" to "dewa, sayounara" } \\
\text { wo yaru kara, }\end{array}$ & $\begin{array}{l}\text { come in?' and 'Goodbye' from } \\
\text { one side of the fence to the other } \\
\text { side of the fence. (domestication } \\
\text { ideology) }\end{array}$ & $\begin{array}{l}\text { someone's home by saying, } \\
\text { "Excuse me", and come out of } \\
\text { the house by saying, " } \\
\text { sayonara" from one end of } \\
\text { the fence to the other end of } \\
\text { the fence. (foreignization) }\end{array}$ \\
\hline 14. & $\begin{array}{l}\text { pg. } 140 \\
\text { それから、‘よーく嚙めよ } \\
\text { たべものを...を、みんなで歌って、「いただきま } \\
\text { 一す」になったにだけど、今度から、この「いた } \\
\text { だきまーす」のあとに、「誰かさんの、“おはなし } \\
\text { ”というのが入ることになったのだ。 } \\
\text { Sorekara, “yo-ku kame yo, tabemono wo...wo,minna de } \\
\text { utatte, “itadakima-su” ni natta no dakedo, kondo kara, } \\
\text { kono "itadakima-su” no ato ni, "dareka-san no, } \\
\text { ohanashi” to iu no ga hairu koto ni natta no da. }\end{array}$ & $\begin{array}{l}\text { After everyone is ready and they } \\
\text { finished singing "Chew your food } \\
\text { thoroughly" followed by "Enjoy } \\
\text { your dinner" someone will } \\
\text { deliver a speech. (domestication } \\
\text { ideology) }\end{array}$ & $\begin{array}{l}\text { But now after saying } \\
\text { "itadakimasu", followed by } \\
\text { "a story by someone" event. } \\
\text { (foreignization ideology) }\end{array}$ \\
\hline 15. & $\begin{array}{l}\text { pg. } 148 \\
\text { シェパードのロッキにとって、狼になるのは、そ } \\
\text { うむずかしいことじゃなかった。 } \\
\text { Shepaado no Rokki ni totte, ookami ni naru no wa, sou } \\
\text { muzukashii koto janakatta. }\end{array}$ & $\begin{array}{l}\text { Rocky is a German Shepherd. } \\
\text { It's not hard for him to grin like a } \\
\text { wolf. (domestication ideology) }\end{array}$ & $\begin{array}{l}\text { For Rocky, a shepherd dog, is } \\
\text { not hard to become a wolf. } \\
\text { (foreignization) }\end{array}$ \\
\hline 16. & $\begin{array}{l}\text { pg.171 } \\
\text { 校長先生や、他の先生に、「行ってまいりまーす } \\
」 \text { をして、全校生徒、五十人が、丸山先生を先頭 } \\
\text { に歩き出した。 } \\
\text { Kouchou sensei ya, hoka no sensei ni, “itte mairimaasu” } \\
\text { wo shite, zenkou seito, go juu nin ga, Maruyama-sensei } \\
\text { wo sentou ini arukidashita. }\end{array}$ & $\begin{array}{l}\text { After saying goodbye to the } \\
\text { principal and teachers, fifty } \\
\text { Tomoe students, who lead by } \\
\text { Mr.Maruyama, leave. } \\
\text { (domestication ideology) }\end{array}$ & $\begin{array}{l}\text { They say greeting to the } \\
\text { principal and teachers by } \\
\text { saying, "ittemairimasu" (We } \\
\text { leave, now.)". (domestication } \\
\text { and foreignization ideology) }\end{array}$ \\
\hline 17. & $\begin{array}{l}\text { pg. } 176 \\
\text { だから、『韓国人!』というのは、人に対しての } \\
\text { 悪口の言葉だと思っているのね。マサオちやんは } \\
\text { 、まだわからないのよ、小さいから、よく、みん } \\
\text { なが、悪口をいうとき、『馬鹿!』なんていうで } \\
\text { しょう? } \\
\text { Dakara, “kankokujin!” to iu no wa, hito ni taishite no } \\
\text { waruguchi no kotoba da to omotteiru no ne. Masao-chan } \\
\text { wa, mada wakaranai no yo, chiisai kara, yoku, minna ga, } \\
\text { waruguchi wo iu toki “baka!" nante iu deshou? }\end{array}$ & $\begin{array}{l}\text { She thought that the word is } \\
\text { similar to the word 'baka' which } \\
\text { said by people if they want to say } \\
\text { 'you stupid'. (domestication } \\
\text { ideology) }\end{array}$ & $\begin{array}{l}\text { So, she tried to called you } \\
\text { 'Chosen people!', as if she } \\
\text { often called like that by other } \\
\text { people. (domestication } \\
\text { ideology) }\end{array}$ \\
\hline 18. & $\begin{array}{l}\text { pg. } 193 \\
\text { 「だから、いまでも、みんなに、ビテイコツ、と } \\
\text { いうのが、残っているんです」といったときは、 } \\
\text { トットちやん始めとしてみんな、お互いに、どれ } \\
\text { が、ビテイコツか、で、教室は、大さわぎになっ } \\
\text { た。 } \\
\text { "Dakara, ima demo, minna ni, betikotsu, to iu no ga, } \\
\text { nokotteirun desu" to itta toki wa, Totto-chan hajime } \\
\text { toshite minna, otagai ni, dore ga, biteikotsu ka, de, } \\
\text { kyoushitsu wa, oosawagi ni natta. }\end{array}$ & $\begin{array}{l}\text { After that, when the teacher } \\
\text { explained that everyone have a } \\
\text { remnant tail which called coccyx, } \\
\text { the children start to guess where } \\
\text { is their remnant tail. } \\
\text { (foreignization) }\end{array}$ & $\begin{array}{l}\text { The story is very interesting. } \\
\text { Especially when the teacher } \\
\text { said, "So, until now, } \\
\text { everybody still have } \\
\text { tailbone." (domestication } \\
\text { ideology) }\end{array}$ \\
\hline 19. & $\begin{array}{l}\text { pg. } 198 \\
\text { トットちゃんは、日比谷公会堂に、バレーの”白鳥 } \\
\text { の湖“を見に連れて行ってもらった。 } \\
\text { Totto-chan wa, Hibiya Koukaidou ni, baree no }\end{array}$ & $\begin{array}{l}\text { Totto-chan invited to Hibiya Hall } \\
\text { to watch Swan Lake ballet } \\
\text { recital. (foreignization) }\end{array}$ & $\begin{array}{l}\text { Totto brought into Hibiya } \\
\text { building to watch "White } \\
\text { Swan Lake" ballet dance. } \\
\text { (domestication ideology) }\end{array}$ \\
\hline
\end{tabular}




\begin{tabular}{|c|c|c|c|}
\hline & Hakuchou no Mizuumi' wo mi ni tsurete itte moratta. & & \\
\hline 20 . & $\begin{array}{l}\text { pg. } 226 \\
\text { トットちゃんは、そのリボンを、先生に、もっと } \\
\text { 、よく見えるように近づけると、得意そうな声で } \\
\text { 「おばあちやんの、昔の袴に、ついていた。 ...」 } \\
\text { Totto-chan wa, sono ribbon wo, sensei ni, motto, yoku } \\
\text { mieru youni chikadzukeru to, tokui sou na koe de, } \\
\text { “obaachan no, mukashi no hakama ni, tsuite ita....” }\end{array}$ & $\begin{array}{l}\text { "This ribbon is in my aunt's } \\
\text { school uniform," she said } \\
\text { proudly. (domestication ideology) }\end{array}$ & $\begin{array}{l}\text { To make it visible, Totto bring } \\
\text { the ribbon closer to the } \\
\text { principal and proudly } \\
\text { answered, "This is from } \\
\text { hakama. A long pleated skirt } \\
\text { which combined with kimono, } \\
\text { my aunt's old used uniform." } \\
\text { (domestication and } \\
\text { foreignization ideology) }\end{array}$ \\
\hline 21. & $\begin{array}{l}\text { pg. } 277 \\
\text { 寝る前に、トットちやんや、他の子供たちの寝る } \\
\text { カヤの中で、「天皇陛下、ばんざい!!」といて、、 } \\
\text { ばったり倒れて戦死する兵隊さんの、まねを、何 } \\
\text { 度も真剣にやるんだけど、 } \\
\text { Neru mae ni, Totto-chan ya, hoka no kodomotachi no } \\
\text { neru kaya no naka de, “Tennou-heika, banzai!!” to itte, } \\
\text { battari taorete senshi suru heitai-san no, mane wo, } \\
\text { nandomo shinken ni yarundakedo, }\end{array}$ & $\begin{array}{l}\text { Before go to bed, Yat-chan } \\
\text { always yell, "Long live our } \\
\text { king!" and then she fell, like a } \\
\text { soldier who getting shot, pretend } \\
\text { to die. (domestication ideology) }\end{array}$ & $\begin{array}{l}\text { Before sleeping in mosquito } \\
\text { net where Totto and her } \\
\text { siblings sleep, she always } \\
\text { playing while seriously } \\
\text { imitating a yell from a soldier } \\
\text { who fell, } \\
\text { 'Tennoheika...Banzai!! } \\
\text { (Long live our king). } \\
\text { (domestication and } \\
\text { foreignization ideology) }\end{array}$ \\
\hline
\end{tabular}

Examples of Translation Ideology Data Analysis by Translator Team Latifah Rahmat and Nandang Rahmat

\begin{tabular}{|c|c|c|c|}
\hline No. & Source Language Texts (SL) & $\begin{array}{l}\text { Target Language Texts (TL) by } \\
\text { Latifah Rahmat and Nandang } \\
\text { Rahmat (L\&N) }\end{array}$ & $\begin{array}{l}\text { Description of Domestication } \\
\text { Reasons }\end{array}$ \\
\hline 1. & $\begin{array}{l}\text { Hlm. } 176 \\
\text { だから、『韓国人!』というのは、人に対しての } \\
\text { 悪ロの言葉だと思っているのね。マサオちゃんは } \\
\text { ¿まだわからないのよ、小さいから、よく、みん } \\
\text { なが、悪ロをいうとき、『馬鹿!』なんていうで } \\
\text { しょう? } \\
\text { Dakara, "kankokujin!” to iu no wa, hito ni taishite no } \\
\text { waruguchi no kotoba da to omotteiru no ne. Masao-chan } \\
\text { wa, mada wakaranai no yo, chiisai kara, yoku, minna ga, } \\
\text { waruguchi wo iu toki “baka!" nante iu deshou? }\end{array}$ & $\begin{array}{l}\text { So, she tried to called you } \\
\text { 'Chosen people!', as if she often } \\
\text { called like that by other people. } \\
\text { (domestication ideology) }\end{array}$ & $\begin{array}{l}\text { Euphemism in the word馬鹿 } \\
\text { (Chosen) for Korean people, is } \\
\text { used to increase text } \\
\text { acceptance if the text is } \\
\text { connected to the event issue or } \\
\text { social phenomenon at that } \\
\text { time. In the similar sentence, } \\
\text { choosen which translated as } \\
\text { 'stupid' in the dictionary, } \\
\text { translated as Korean people by } \\
\text { the translator. }\end{array}$ \\
\hline 2. & $\begin{array}{l}\text { Hlm. } 198 \\
\text { トットちゃんは、日比谷公会堂に、バレーの”白鳥 } \\
\text { の湖“を見に連れて行ってもらった。 } \\
\text { Totto-chan wa, Hibiya Koukaidou ni, baree no } \\
\text { "Hakuchou no Mizuumi’ wo mi ni tsurete itte moratta. }\end{array}$ & $\begin{array}{l}\text { Totto brought into Hibiya } \\
\text { building to watch "White Swan } \\
\text { Lake" ballet dance. } \\
\text { (domestication ideology) }\end{array}$ & $\begin{array}{l}\text { baree no "Hakuchou no } \\
\text { Mizuumi' translated as "White } \\
\text { Swan Lake" ballet dance. The } \\
\text { purpose of the domestication } \\
\text { is to make the target reader } \\
\text { understand the text well. }\end{array}$ \\
\hline
\end{tabular}

Translator team Latifah Rahmat and Nandang Rahmat translated this book in translation project which sponsored by Toyota Foundation. This project contains Japanese culture and language awareness mission so the language terminologies and Japanese culture introduce to the target language reader as 
much as possible. Besides that, the occupation of translator team as Japanese language lecturers, make it possible for them to be familiar to use Japanese culture terminologies and also explained the meaning of them. This can be seen in the data which showed that the highest translation ideology is foreignization and domestication ideologies. The amount of those ideologies are 32 from 73 data, which is $44 \%$. The team reponsibility to Toyota Foundation in the Madogiwa no Totto-chan novel translation project, and their dedication as Japanese Language and Literature lecturers made the translator team chose domestication and foreignization ideologies. From 73 data, only 15 data which is only $20 \%$ of the data which used foregnization ideology, and 26 from 73 data, which is $36 \%$ of the data which used domestication ideology. It showed that the translator team tried to use domestication strategy as much as possible, to make it easier for the reader to understand the story in this Madogiwa no Totto-chan novel. In general, the translation result of the translator team is more complete, because the source language (SL) which contains quotations of how is the pronunciation of a little girl who is a Japanese speaker in receiving the language, translated as it is. Because in this matter, the pronunciation could not be transferred to another sound. For example in the sentences below:

a) A little boy who is Totto's childhood friend, when he said sekken no abuku (soap bubble) will always be chenken no abuke.

b) There is someone who wants to said Kangofu-san (suster) but it pronounce as kangokusan.

In a simple way, translator, as a text processor, is filtering the text world from source text through their own point of view or ideology, with a different result. The level of translator mediation is not always in line with the domestication level.

In the translating case of Korean people as Choosen people, which is vague between stupid and Korean people as the meaning, is according to translation pattern of Harvey (1998-2000) which explain the reason that he gave the translation which include some characteristics that can not be appear, and it is done with the text harmonization by using harmonization of human subjective view in order to produce a cultural target. The cultural target which mention in this matter is the east culture target especially in a children novel with education genre like this Madogiwa no Totto-chan novel. In this case, the tendency which can be seen as mediation level are when the translator get involved in the transfer process, giving their own knowledge and believe in processing the text, for example through euphemism.
From Post Structuralist point of view which chose by the translators, Latifah Rahmat and Nandang Rahmat, is like Spivak explanation. He said that translation is come from literal translation with a high understanding from a wide thoughts area from the authentic one, and an awareness from different cultural context. Translator must be able to creates a nice thoughts and also what they feel is contrast with the distance in the Target Language which can make a reaction from the distance in the source language. In the analysis above, it can be seen that the variation of translation ideology which can be interpreted from two very different culture. His choice which point to post-structuralist is for literal translation with a wide understanding to the region involved, from the authenticity and an awareness of different cultural context.

In his theory study, Bassnet (1980/1991: xv) said that "A translator who taking a text and transfer it into cultural purposes, have to consider the meaning of the ideoloy from the transfer process accurately. Remember that even though cultural transfer had been studied in the translation for years, there will be some differences which can not be denied about what 'culture' and 'ideology' really is (See Fawcet 1998:106). Even though 'cultural transfer' used in general expression for non-linguistic translation studies. Sherry Simon illustrate how culture and language have interaction in translation:

Translators must constantly make decision about the cultural meanings which language carries, and evaluate the degree to which the two different worlds they inhabit are 'the same'... In fact the process of meaning transfer has less to do with finding the cultural inscription of a term than in reconstructing its value.

(Simon 1996:139) ${ }^{11}$

Latifah Rahmat dan Nandang Rahmat also do cultural transition process in translating ideology and culture terms such as word: Chindonyasan which is socio-cultural term (a clown who is strolling around with music and advertise new grocery store) translator doesn't find the exact equivalent culture in target language, and even word 'Chindonyasan' is rarely found in dictionary and translated as 'a clown who advertises new things'. Latifah Rahmat as a native speaker surely could understand the meaning of that word. (data 2)

\footnotetext{
${ }^{11}$ Hatim and Munday, Translation An Advanced

Resource Book, Unit C.13 Peralihan budaya dalam

kajian Terjemahan.
} 
Term 'kokki' which refers to socio-political organization and administration in Japanese dictionary_ Indonesian Kenji Matsura means national flag, because in the sentence refers to the context of Japan's national flag (Hinomaru). Therefore, translator directly translates it through modulation technique which is Hinomaru. However, to avoid misperception it usually uses phrase Nihon no Kokki (Japan's National flag) or Indonesia no Kokki (Indonesia's National flag). (data 5)

Term Gunkanki which also refers to sociopolitical organization and administration in Japanese dictionary_ Indonesian Kenji Matsura means 'war ship flag' by translator it is translated as 'war ship flag'. But how young Totto-chan could understand that flag, translator do translation technique which is descriptive equivalent to put the explanation 'similar in Asahi Shinbun news' even though it doesn't exist in target text. 'Asahi Shinbun' is one of newspaper published in Japan. However, word 'shinbun' does not mean 'newspaper' therefore several translators translate it as 'Asahi newspaper' or 'Asahi Shinbun newspaper'. (data 6)

It's similar with the word 'Seinendan' which refers to youth coalition organization, because the novel tells about children then translator simplifies it to be 'youth coalition' and it is written completely with descriptive equivalent as seinendan, youth coalition. (data 7) .

Utterance 'itidakimasu' is one of Japanese principle to express before they want to eat, because it is dominant culture so the translator does borrowing technique by quoting and adding foot note.

Word 'Tengu" in Japan-Indonesia dictionary Matsura' means as: 1.long nose giant; 2.arrogant; big headed person. Translator translates it as 'mythical creature with magical power'. In this translation process, there is euphemism on Japanese myths. Besides that, translator also always tries to show positive nuance on every roles in this book. It is purposed to respect Japanese culture, tradition and myth. Most importantly, this novel is considered as education novel.

The meaning of author's name Tetsuko is written with kanji words 'Tooru' or 'Tetsu' which is explained not based on the meaning of those kanji, but bases on the elements of name establishment Tetsuko. Using of borrowing translation technique because related to dominant culture of Japan which is the meaning of Japanese's name with kanji letters. It is suitable with Japanese personality that does not show individual side, and then translator understands this culture and translated what it is. Word 'tetsu' means 'iron' and 'ko' means 'children'. So name 'Tetsuko' means a child with steel power.

Utterance 'tadaima' is one culture tradition of Japanese to greet people after they arrive in home. When translating that word, translators apply descriptive technique of translation by adding explanation in brackets (I come). 'Tadaima' is written as what it is by Japanese because it is dominant culture of Japanese. Therefore, it is better to use borrowing technique.

For number writing in report book in school is using kanji letter such as ' $k o$ ' and 'otsu'. 'Ko' means good and 'otsu' means evaluation, It is translated by using borrowing technique and only be explained as 'school score'.

Word 'Banzai' which means cheering version of Japanese, in Bahasa Indonesia means as 'hurray!'. But actually the spirit which is carried by word 'banzai' is quite deep and not equal to word 'hurray!' therefore translator chooses borrowing technique using foreignization procedure because it is dominant culture in Japanese language and no equivalent translation. However sometimes word 'Banzai' is translated 'live....!' as cheering and supporting words.

Word 'Benten' in Japan-Indonesia dictionary Kenji Matsura means 'Goddess of Fortune' which is translated as 'Goddess of Happiness'. The reason for choosing this technic is to make the reader understand and the meaning is also more universal. (data 43)

Word '“yonjuu nana shi ga uchiiri' is translated as the attack of forty seven samurai. This translation uses literal technic according to the meaning of the word. (data 60)

Term 'Tennoheika' which refers to sociopolitical organization and administration in Japanese dictionary_ Indonesian Kenji Matsura means 'Sri Baginda Kaisar', and it is translated as 'Caesar' because this is sounded more communicative. Word 'Tennoheika' is equivalence with word 'Banzai', so 'Tennoheika....Banzai!' is translated as 'Live...Caesar!'

The strategy of domestication and foreignization support Basnet's theory that stated all texts as part of literature works which is hereditary and correspond to other system as the result of translation. Every text is unique and the result of other translation text. There is no original text because basically language is a translation of nonverbal world to sign and symbol. But, this strategy of domestication and foreignization accommodates ElDali's view which is contradictory with Basnet's view. He stated that all texts are original because every translation is special. Translation, in one point, is an invention and becoming unique text. Therefore, 
choosing strategy of domestication and foreignization is valid to become ideology of translation, because there is no completely original text because basically language is a translation of non-verbal world to sign and symbol. However, from other view all texts are original because every translation is special. Translation, in one point, is an invention and becoming unique text.

Through the selection of domestication and foreignization strategy, translator is intended to give culture knowledge from source text comprehensively. It is not totally different with Nabokov's (1964) that opposes free translation, because in this strategy translator really observes the equivalent element, so that is not free translation. Moreover, translator's option as lying between two polarities such as 'free" and 'literal' ,'dinamyc equivalence" and 'formal equivalence' (Nida 1964); 'communicative' and 'semantic'translating (Newmark 1981), which those choices show a dicotomy, it is not dillema anymore in choosing strategy of domestication and foreignization at once. Besides that, Newmark's (1981:62) notes that the choice between communicative and semantic is partly determined by orientation towards the social or the individual, that is, towards mass readership or towards the individual choice of the text producer. The choice is implicitly presented as ideological.

The choice of domestication and foreignization strategy responds Venuti's view about the ideological consequence from every choice, either domestication or foreignization. However, the choice of domestication and foreignization strategy at once is wise ideology of translation that supports the purpose of Toyota Foundation and team of translators. The result of translation is hoped as media to transform knowledge about education principles of Japanese and as education material of language, culture and literature of Japan.

If we observe from genetic factors that underlie translation ideology of Novel Madogiwa ni Totto-chan, genetic factors from translator Nandang Rahmat such as he is an Indonesia with east culture as well as moslem with ideology of Pancasila. The ideology of Pancasila is suitable with the ideology of moslem which is Al-Quran. In the way he chooses works that will be translated, he is very selective choosing works that do not contradict with east culture and Islam syariat. Besides that, Nandang Rahmat is also a teacher of Japanese language. Therefore, novel Madogiwa no Totto-chan is one of ideal choice to be translated in Bahasa Indonesia so it could be read by parents, educators, students, language and Japanese culture enthusiast and all age of society.
If we identify as whole, the purpose of domestication strategy being chosen by translators Widya Kirana in this novel is to ease reader's understanding, including children because this novel is universal for all ages, even though it is children's book. Besides that, to make the pronunciation is easier for target reader and it doesn't sound like translation text. Another purpose is to omit half of detail information and figures that doesn't recognize by target readers. Domestication of this novel is also to improve text acceptance if it is related with social phenomenon at that time. But the general purpose of domestication in this novel is to be well accepted by target readers.

Domestication that reflects dominant cultural value from target language's reader create illusion transparency which is the difference of linguistic and domesticated culture' (Venuti 1995:34). Foreign value domestication is important process doing by translators consciously to achieve certain impacts such as to assimilate dominant culture or hegemonic, that is different for target reader's culture. Through the choice of domestication and foreignization at once, translators are avoided from choices of ideology (domestication or foreignization), like usually showed by other translators as personal preference that could be seen as commitment. Translators team Latifah Rahmat dan Nandang Rahmat believe in domestication and foreignization strategy at once in translating, for the sake of comprehensive reader's knowledge.

\section{3) Recommendation}

In foreign language department, translation course should be taught in early semester. This is an effort to train students on how to translate source text into target text, because translating is developed as well as speaking ability.

Translator should have two perspectives in translating. First, how to upgrade translation as thinking category which translators are considered as creative and jenius person. Therefore, translators always enrich literature and language on translating. Besides that, translators should be able to seek more mechanical function such as 'make the text to be known' or make the author to be known.

Concept of ideology in translation also should be delivered as part of translation discussion, related to the relativity and subjectivity in this problem with the purpose that the translator want to achieve beside convincing the reader about the accuracy of the translation. This is also widest scope of political translating action. 


\section{REFERENCES}

Anton Kurnia, Dunia Tanpa Ingatan: Sastra, Kuasa, Pustaka, Jalasutra, Yogyakarta: 2004

Anton Kurnia, Ensiklopedia Sastra Dunia,

I:Boekoe, Jakarta: 200

Anton Kurnia, intersastra, Penerjemahan Sastra, Sebuah Pandangan: majalah sastra Horison edisi Oktober 2011

Baker, M. (1992). In Other Words, A Coursebook on Translation. London : Routledge, 11 New Fetter Lane, EC4P 4EE

Baker, M.(1998). Routledge Encyclopedia of Translation Studies. London: Routledge

Basil Hatim and Jeremy Munday. An Advanced Resource Book

Ben-Ari, Nitsa. 2004. Ideologi and Translation. http://www.inst.at/trans

/16Nr/09_4/ben-ari_bericht16.htm

Brown, Dan. 2003. The Da Vinci Code (Novel). New York: Doubleday.

2003. The Da Vinci Code (Novel terjemahan). Jakarta: Serambi Ilmu Semesta.

Bassnett, S. (2005). Translation Studies Third Edition. New York: the Taylor \& Francis e-library.

Basil Hatim and Jeremy Munday. Translation:An Advanced Resource Book. Routledge:USA hlm. 102111

Bell, R. T. (1991). Translation and Translating: Theory and Practice. New York: Longman Group.

Catford, J. C. (1978). A Linguistic Theory of Translation: An Essay in Apllied Linguitics. Great Britain: Oxford University Press.

Duff, Alan. 1981.The Third Language: Recurrent Problems of Translation into English. England: Pergamon Press, Ltd.

El-dali, H. M. (2010). Towards an Understanding of the Distinctive Nature of Translation Studies. Journal of King Saud University - Language and Translation , 23, 29-45.

Hatim, B., \& Mason, I. (1997). The Translator as Communicator. New York: Routledge.Larson, M.L.(1984). Meaning-Based Translation, a guide to Cross Language Equivalence. USA: University Press of America.

Fawcett, Peter 1998. "Strategies on Translation" in Baker. Encyclopedia of Translation Studies. London\& NewYork : Routledge: 107

Hatim, Basil \& I Mason. 1997. The Translatoras Communicator. London\& NewYork : Routledge.

Hatim, Basil \& Jeremy Munday. 2004. Translataion; An Advance resource Book. Guildfork, UK:University of Surrey

Hoed, Benny. 2003. Ideologi dalam Penerjemahan . konas Penerjemahan. Solo
Karoubi, Behrouz. (2008). Ideologi and Translation with a concluding point on translation teaching. TranslationDirectory.com

Larson, Mildred A. 1984. Meaning-Based Translation. Lanham: University Press of America.

Basil Hatim and Jeremy Munday. Translation:An Advanced Resource Book. Routledge:USA hlm. 102111

Bell, Roger $\mathrm{T}$. Translation and Translation Theory and Practice. London dan NewYork: Longman. 1997.

Damono, Sapardi Djoko. Sosiologi Sastra. Jakarta: PustakaFirdaus. 1984.

Emzir dan Saifur Rohman.Teori dan Pengajaran Sastra. Jakarta: Rajawali Pers. 2015.

Esten, Mursal. Kesusastraan : Pengantar Teori dan Sejarah. Bandung: Angkasa. 1978.

Fananie, Zainuddin.Telaah Sastra, (Surakarta: Muhammadiyah University Press, 2002

Faweet, Peter. Translation and Language: Linguistic Therories Explained .United Kingdom: Stjerome Publishing. 1997.

Jefferson \& Robey, Ann \& David (ed), Modern Literary Theory (Second Edition).London: B.T. Batsford Ltd. 1987.

Luxemburg, J. Van, et. All. Pengantar Ilmu Sastra .Jakarta: Gramedia. 1984

Hatim, B., \& Munday, J. (2004). Translation: An Advance Resource Book. New York: the Taylor \& Francis Group.

Hatim, Basil dan Jeremy Munday Dalam Nida. Translation: An Advanced ResourceBook. London dan Newyork: Roudledge. 2004.

Kempson, Ruth M. Semantic Theory. Cambridge: Cambrifge University Press.1986.

Larson, Mildred L. Meaning Based Translation :A Guide to Cross-language Equivalence. Boston Way: University Press of America. 1988.

Lyons, John. Language, Meaning dan Context . Sulfolk:Fontana. 1989.

Machali, Rochayah. 2000. Pedoman bagi Penerjemah. Jakarta: Grasindo.

Mazi, Darja. Leskovar. 2003. Domestication and Foreignization in Translating American Prose for Slovenian Children. Meta Vol XLVIII, 1-2

McRae, J. \& Pantaleoni, L. Words on the Page, A Course in English Literature. Italy: Nuova Edizione, La Nuova Italia \& Oxford University Press. 1994.

Mario Klarer, An Introduction to Literary Studies, Second Edition, (London \& New York: Routledge Taylor \& Francis Group, 2005. 
Miller, James et. al., Man in Literature: Comparative World Studies in Translation, Scott, Foresman, Atalanta: 1977

Nida, Eugene A. dan Charles R. Nida. The Teory and Practice of Translation. Leiden: Published For The United Bible Societis. 1982.

Nurgiyantoro, Burhan, Teori Pengkajian Fiksi. Yogyakarta: Gajah Mada University Pres. 2013.

Newmark, P. (1988). A Textbook of Translation. New Jersey: Prentice Hall Int. Limited.

Pradopo, Rachmat Djoko. Beberapa Teori Sastra, Metode Kritik, dan Penerapannya. Yogyakarta: Pustaka Pelajar. 2007.

Pym, Anthony. 2006. localization in the Perspective of Translation Studies: Overlap in the digital Devide. Meta

Ratna, Kutha Nyoman. Postkolonialisme Indonesia Relevansi Sastra. Y

ogyakarta: Pustaka Pelajar. 2008.

Richards, J. C., \& Schmidt, R. (2010). Longman Dictionary of Language Teaching and Applied Linguistics Fourth Edition . Malaysia: Pearson Education Limited.

Rahyono, FX. Studi Makna. Jakarta: Penaku. 2012.

Rudolf Nababan (2003). Teori Menerjemahkan Bahasa Inggris. Pustaka Pelajar Offset

Suryawinata, Zuchridin \& Sugeng Hariyanto. 2003. Translation: Bahasan Teori dan Penuntun Praktis Menerjemahkan. Yogyakarta: Kanisius..

Sastriyani, Siti Hariti, Karya Sastra Perancis Abad ke-19 Madame Bovary dan Resepsinya di Indonesia. Dalam Jurnal Humaniora, Volume XIII, No. 3/2001, hlm. 252-259 .Yogyakarta: Gajah Mada University Press. 2001.

Suminto Ahmad Sayuti, Citra Estetika Islam dalam Sajak-Sajak Indonesia Mutakhir: Beberapa Catatan Awal", Prosiding Seminar Bahasa dan Sastra, (Brunei Darussalam: Dewan Bahasa dan Pustaka: 2004

Teeuw, A. Sastra dan Ilmu Sastra. Jakarta: Pustaka Jaya. 2013

Wellek, Rene dan Austin Warren. Teori Kesusastraan. Terjemahan. Jakarta: Gramedia. 1989.

Wijana, I Dewa Putu. Pengantar Semantik Bahasa Indonesia. Yogyakarta: Pustaka Pelajar. 2010. 